\title{
PENERAPAN TERAPI PENERIMAAN DAN KOMITMEN UNTUK MENGURANGI KECEMASAN PADA NARAPIDANA MENJELANG PEMBEBASAN BERSYARAT DI LAPAS X
}

\author{
Mario Carl Joseph ${ }^{1}$ \\ Fakultas Psikologi, Universitas Tarumanagara \\ Email: josephmariocarl@gmail.com
}

\begin{abstract}
ABSTRAK
Predikat bekas narapidana memberikan beban yang amat berat, penuh tantangan dan pandangan penuh curiga dari masyarakat kepada setiap mantan narapidana. Narapidana yang akan kembali ke tengah masyarakat memiliki beberapa reaksi emosional, salah satunya adalah kecemasan. Penelitian ini menggunakan metode kualitatif untuk menggambarkan kecemasan narapidana dan metode kuantitatif untuk melihat peran terapi penerimaan dan komitmen dalam mengurangi kecemasan narapidana menjelang pembebasan. Kecemasan pada narapidana diukur dengan Beck Anxiety Inventory yang mengandung 21 pertanyaan berfokus pada gejala somatik kecemasan. Subyek dalam penelitan ini adalah 5 narapidana yang mengalami kecemasan. Teknik pengambilan sample menggunakan metode purposive sampling. Pemberian terapi penerimaan dan komitmen pada 5 subyek penelitian sebanyak 5 sesi. Dalam penelitian ini, terapi penerimaan dan komitmen terbukti dapat mengurangi kecemasan pada warga binaan menjelang pembebasan bersyarat dengan menunjukan perubahan ke arah yang positif. Keberhasilan terapi penerimaan dan komitmen juga dipengaruhi oleh dukungan yang diberikan dari masing-masing narapidana sebagai sebuah kelompok (kelompok dukungan).
\end{abstract}

Kata Kunci: Kecemasan, Terapi Penerimaan dan Komitmen

\section{PENDAHULUAN}

Kehidupan seorang narapidana dalam Lembaga Pemasyarakatan berbeda dengan kehidupan seseorang yang tinggal di luar Lembaga Pemasyarakatan. Sunaryo (2016) menjelaskan bahwa kehidupan di penjara merupakan suatu kehidupan yang tidak "wajar". Menurut Sunaryo penjara adalah suatu kehidupan yang merupakan antitesis terhadap prinsip-prinsip kebebasan memilih dalam suatu masyarakat bebas.Mereka tidak dapat merasakan kebebasan seperti kehidupan di luar Lembaga Pemasyarakatan. Kondisi ini dikemukakan Mulyadi (2005) sebagai akibat bahwa pidana penjara merupakan pidana bersifat perampasan kemerdekaan pribadi terpidana karena penempatannya dalam bilik penjara.

Penelitian yang dilakukan Zamble dkk (dalam Bartol, 1994) menjelaskan bahwa secara umum dampak kehidupan di penjara merusak kondisi psikologis seseorang. Studi ini mendeskripsikan gejala-gejala psikologis yang diakibatkan oleh pemenjaraan terhadap seseorang. Gejala-gejala psikologis yang muncul meliputi depresi berat, kecemasan, dan sikap menarik diri dari kehidupan sosialnya. Hal ini sejalan penelitian Mitchell (2010) yang menemukan bahwa masalah kesehatan mental tertinggi ada di penjara.

Dalam penelitian yang dilakukan oleh Fahruliana (2011) ditemukan bahwa munculnya kecemasan pada narapidana umumnya saat menjelang masa pembebasan. Hal ini sejalan dengan hasil wawancara terhadap lima narapidana menjelang bebas yang dilakukan oleh Utari dkk (2013) ditemukan bahwa dampak kecemasan yang dirasakan oleh warga binaan ialah emosi yang meningkat secara tiba-tiba, lebih banyak melamun, menangis, tertutup terhadap sesama penghuni lapas dan mudah curiga terhadap orang lain. Salah satu penyebab kecemasan yang dirasakan oleh warga binaan adalah kekhawatiran akan pandangan masyarakat terhadap seorang mantan narapidana, peran sebagai orang tua bagi anak-anak, penerimaan anak terhadap orang tua mantan narapidana, peran pasangan dan cemas menanti untuk bisa berkumpul bersama keluarga. Dalam 
penelitian tersebut ditemukan pula sebanyak $38 \%$ dari 50 responden adalah memiliki tingkat kecemasan berat, sebanyak 28\% kecemasan sedang, dan sebanyak 34\% kecemasan ringan.

Atwater (1983) mendefinisikan kecemasan sebagai perasaan tidak nyaman dan ancaman bahwa sesuatu yang buruk akan terjadi. Sedangkan Taylor (1995) mengemukakan bahwa, kecemasan adalah suatu pengalaman subjektif mengenai ketegangan mental yang menggelisahkan yang merupakan reaksi umum dan ketidakmampuan menghadapi masalah atau adanya rasa tidak aman. Sejalan dengan pendapat yang dikemukakan sebelumnya, kecemasan menurut Hilgard (1996) adalah emosi yang tidak menyenangkan yang ditandai dengan kekhawatiran, keprihatinan, dan rasa takut yang terkadang dialami oleh individu dalam tingkat yang berbeda-beda.

Hasil penelitian yang dilakukan oleh Aini (2015) terhadap narapidana menjelas pembebasan, ditemukan bahwa intervensi Cognitive Behavior Therapy terbukti dapat mengurangi derajat kecemasan pada masing-masing partisipan yang ditandai dengan berkurangnya simtom-simtom kecemasan. Terapi lain yang telah dikembangkan oleh Zettle dan Hayes (1986) adalah Acceptance and Commitment Therapy. Forman dkk (dalam Hayes, 2010) menjelaskan bahwa terapi penerimaan dan komitmen dapat digunakan untuk menangani masalah kecemasan.

Pada penelitian ini mengambil subyek lima narapidana yang menjelang pembebasan di Lapas X. Penelitian tentang penerapan terapi penerimaan dan komitmen untuk mengurangi kecemasan narapidana menjelang pembebasan juga masih sangat sedikit ditemukan dalam literatur. Untuk itu penulis tertarik untuk melakukan penelitian dengan terapi penerimaan dan komitmen dalam mengurangi kecemasan narapidan menjelang pembebasan.

\section{LANDASAN TEORI}

\section{Acceptance dan Commitment Therapy}

Acceptance dan Commitment Therapy (ACT) merupakan suatu terapi yang bertujuan untuk meningkatkan aspek psikologi yang lebih fleksibel atau kemampuan untuk menjalani perubahan yang terjadi saat ini dengan lebih baik (Hayes, 2007). Dalam ACT, klien diajak untuk tidak menghindari tujuan hidupnya, meskipun dalam upaya untuk mencapainya akan ditemukan pengalaman-pengalaman yang tidak menyenangkan.

Menurut Stroshal (2002), tujuan ACT adalah : (a) Membantu klien menggunakan pengalaman langsung untuk mendapatkan respon yang lebih efektif dan tetap bertahan dalam hidupnya; (b) Mampu mengontrol penderitaan yang dialaminya; (c) Menyadari bahwa penerimaan dan kesadaran merupakan upaya alternative untuk tetap bertahan dalam kondisi yang dihadapinya; (d) Menyadari bahwa penerimaan akan terbentuk oleh adanya pikiran dan apa yang diucapkan; (e) Menyadari bahwa diri sendiri sebagai tempat penerimaan dan berkomitmen melakukan tindakan yang akan dihadapi; (f) Memahami bahwa tujuan dari suatu perjalan hidup adalah memilih nilai dalam mencapai hidup yang lebih berharga.

Terapi ACT dapat digunakan dalam menangani masalah : (1) Kecemasan (Forman, et, al 2007 dalam Hayes, 2010) dan beberapa peneliti lainnya; (2) menangani masalah penyakit kronik (McCracken, MacKitchan, dan Eccleston, 2007, dalam Hayes, 2010) dan beberapa peneliti lainnya; (3) Depresi (Lappalainent, 2007, dalam Hayes 2010) dan beberapa peneliti lainnya; (4) Gangguan pola kebiasaan (Wood, Wterneck, dan Flessnes, 2006, dalam Hayes, 2010) dan beberapa peneliti lainnya; (5) Masalah psikotik (Gaudiano dan Herbert, 2006, dalam Hayes 2010) dan beberapa peneliti lainnya. 


\section{Kecemasan}

Menurut Aaron T. Beck (1993), kecemasan berada pada garis kontinum yang sama dengan pengalaman emosional lainnya, dan setiap semua pengalaman emosional berkaitan dengan kognisi. Setiap emosi berhubungan dengan tema kognitif tertentu dan kecemasan dikaitkan dengan tema "ancaman", "bahaya" dan "mudah diserangee. Kecemasan merupakan hasil dari penafsiran yang berlebihan tentang suatu bahaya atau kepercayaan yang terlalu rendah pada coping atau kemampuannya.

Haber dan Runyon (1984) menjelaskan terdapat 4 dimensi kecemasan yaitu: 1) Dimensi Kognitif (dalam pikiran seseorang). Dimensi kognitif yaitu perasaan tidak menyenangkan yang muncul dalam pikiran seseorang sehingga ia mengalami perasaan risau dan khawatir. Kekhawatiran ini dapat terjadi mulai dari tingkat khawatir yang ringan lalu panik, cemas, dan merasa akan terjadi malapetaka, kiamat, serta kematian. Saat individu mengalami kondisi ini ia tidak dapat berkonsentrasi, tidak dapat mengambil keputusan, dan mengalami kesulitan untuk tidur.Termasuk dimensi kognitif antara lain menjadi sulit tidur di malam hari, mudah bingung, dan lupa; 2) Dimensi Motorik (dalam tindakan seseorang). Dimensi motorik yaitu perasaan tidak menyenangkan yang muncul dalam bentuk tingkah laku seperti meremas jari, jari-jari \& tangan gemetar, tidak dapat duduk diam atau berdiri di tempat, menggeliat, menggigit bibir, menjentikkan kuku, gugup, dan mengambangkan Tics. Biasanya orang yang cemas menunjukkan pergerakan secara acak; 3) Dimensi Somatis (dalam reaksi fisik/biologis). Dimensi somatis yaitu perasaan yang tidak menyenangkan yang muncul dalam reaksi fisik biologis seperti mulut terasa kering, kesulitan bernafas, jantung berdebar, tangan dan kaki dingin, diare, pusing seperti hendak pingsan, banyak berkeringat, tekanan darah naik, otot tegang terutama kepala, leher, bahu, dan dada, serta sulit mencerna makanan; 4) Dimensi Afektif (dalam emosi seseorang). Dimensi afektif yaitu perasaan tidak menyenangkan yang muncul dalam bentuk emosi, perasaan tegang karena luapan emosi yang berlebihan seperti dihadapkan pada suatu teror. Luapan emosi ini biasanya berupa kegelisahan atau kekhawatiran bahwa ia dekat dengan bahaya padahal sebenarnya tidak terjadi apa-apa. Termasuk dimensi afektif antara lain yaitu merasa tidak pasti, menjadi tidak enak, gelisah, dan menjadi gugup (nervous).

Faktor-faktor yang mempengaruhi kecemasan menurut Stuart \& Sudden (1998), yaitu: 1) Faktor eksternal berupa ancaman integritas diri, meliputi ketidakmampuan fisiologis atau gangguan terhadap kebutuhan dasar (penyakit, trauma fisik, pembedahan yang akan dilakukan) dan ancaman sistem diri, seperti ancaman terhadap identitas diri, harga diri, hubungan interpersonal, kehilangan, dan perubahan status dan peran; 2) Faktor internal berupa potensial stressor, maturitas, pendidikan, respon koping, status sosial ekonomi, keadaan fisik, tipe kepribadian, lingkungan dan situasi, dukungan sosial, usia, humor dan jenis kelamin.

\section{Pembebasan Bersyarat}

Pembebasan bersyarat (PB) adalah proses pembinaan Narapidana di luar LAPAS setelah menjalani sekurang-kurangnya $2 / 3$ (dua pertiga) masa pidananya minimal 9 (sembilan) bulan (Pasal 1 PP Nomor 32 Th.1999 tentang Syarat dan Tata Cara pelaksanaan Hak Warga Binaan Pemasyarakatan). Izin Pembebasan bersyarat (PB) dapat diberikan kepada narapidana apabila yang bersangkutan : 1) Dipidana untuk masa satu tahun atau lebih, baik dalam satu atau beberapa putusan; 2) Telah memenuhi persyaratan sebagaimana dimaksud Pasal 7, Pasal 8 huruf a, b, c, d, e dan f angka 2 dan Pasal 9 Permenkeh RI No. M.01-PK.04.10 Th.1989 tentang Asimilasi, Pembebasan bersyarat dan Cuti Menjelang Bebas dan bagi narapidana tertentu, sebagaimana 
dimaksud dalam Pasal 1 Permenkeh RI No. M.01-PK.04.10 Th.1991 tentang Penyempurnaan Permenkeh RI No. M.01-PK.04.10 Th.1989 tentang Asimilasi, Pembebasan bersyarat dan Cuti Menjelang Bebas, telah pula memenuhi persyaratan sebagaimana dimaksud dalam Pasal 3 huruf a dan b Permenkeh RI No. M.01- PK.04.10 Th.1991; 3) Tidak termasuk narapidana sebagaimana dimaksud dalam Pasal 2 Permenkeh RI No.M.01-PK.04.10 Th.1991 tentang Penyempurnaan Permenkeh RI No.M.01-PK.04.10 Th.1989 tentang Asimilasi, Pembebasan bersyarat dan Cuti Menjelang Bebas; 4) Telah memenuhi persyaratan administrasi lainnya.

Pemberian izin Pembebasan bersyarat adalah wewenang Menteri Kehakiman dan HAM yang dalam pelaksanaannya didelegasikan kepada Direktur Jenderal Pemasyarakatan. Narapidana yang memperoleh PEMBEBASAN BERSYARAT harus memenuhi syarat-syarat : 1) Telah menjalani 2/3 dari masa pidana yang sebenarnya, minimal 9 bulan; 2) Tanggal 2/3 dari masa pidana yang sekarang dihitung sejak tanggal eksekusi jaksa; 3) Tidak sedang menjalani Hukuman Disiplin Pembebasan bersyarat adalah pemberian pembebasan dengan beberapa syarat kepada narapidana yang telah menjalani pidana selama dua pertiga dari masa pidananya, di mana dua pertiga ini sekurang-kurangnya adalah selama sembilan bulan. Setelah bebas dari lapas selain dibebani oleh beberapa syarat, narapidana juga diberikan tambahan masa percobaan selama setahun dan langsung ditambahkan pada sisa pidananya (Suhardi, M, 2005).

\section{METODE PENELITIAN}

Subyek dalam penelitian ini memiliki karakteristik : (a) warga binaan yang sekurang-kurangnya telah menjalani 2/3 dari masa pidananya, (b) Berusia 20 - 40 tahun, (c) Mengalami kecemasan, (d) Merupakan warga binaan Lapas Kelas IIA Narkotika Cipinang. Pada penelitian ini ada 5 subyek yaitu AN (40 tahun), MD (32 tahun), SH (26 tahun), I (32 tahun) dan AD (28 tahun).

Kumar (1999) membagi penelitian berdasarkan frekuensi pengambilan data (number of contacts), waktu terjadinya gejala (reference of period), dan nature of investigation. Berdasarkan nature of investigation, penelitian ini tergolong sebagai penelitian non-experimental, karena tidak adanya treatment pada data yang digunakan untuk melihat pengaruh dari suatu variabel. Teknik pengambilan sampel adalah purposive sampling karena peneliti menilai sendiri siapa yang dapat memberikan informasi terbaik untuk mencapai tujuan dari penelitian.

Penelitian ini menggunakan pendekatan metode kualitatif sebagai metode utama dan metode kuantitatif sebagai metode pendukung. Metode kualitatif digunakan untuk memberikan gambaran kecemasan yang dialami warga binaan, yaitu penyebab kecemasan, perilaku keseharian selama berada di lapas dan perubahan kecemasan. Metode kuantitatif melalui pre-post test digunakan untuk melihat peran acceptance dan commitment therapy dalam mengurangi kecemasan.

Penelitian ini dilakukan di Lapas X. Instrumen yang digunakan dalam penelitian ini adalah skala pengukuran kecemasan yaitu Back Anxiety Inventory (BAI) dan tes grafis seperti Draw A Person (DAP), BAUM dan House Tree Person (HTP).

\section{HASIL DAN PEMBAHASAN}

Ketika warga binaan telah menjalani 2/3 masa tahanan dan mendapat kesempatan untuk diberikan pembebasan bersyarat maka akan menimbulkan beberapa reaksi emosional seperti takut, cemas, khawatir dan merasa bersalah karena telah membuat keluarga kecewa sehingga menjalani hukuman di dalam Lapas. Pada subyek AN cemas karena merasa bersalah terhadap anak dan takut 
anak akan membenci dirinya, subyek MD merasa cemas karena merasa mertua menghasut istri untuk meninggalkan dirinya, subyek SH merasa cemas karena merasa bersalah terhadap anak dan takut gagal karena tidak memiliki kemampuan sebagai orang tua, subyek I merasa cemas karena takut tidak dapat mengendalikan emosi ketika menghadapi masalah, subyek AD merasa cemas karena istri mulai menjauh dan takut istri akan meninggalkan dirinya.

\section{Gambaran Pelaksanaan Program Intervensi}

Pelaksanaan program intervensi terdiri dari 5 sesi dengan durasi pertemuan 1,5 jam setiap sesi dan dilakukan di ruangan kelas yang berada di Lapas X. Tahap pertama yaitu acceptance dan cognitive defusion. Tahap ini bertujuan untuk membantu anggota kelompok agar mampu mengidentifikasi kejadian yang tidak menyenangkan sampai saat ini. Tahap ini juga bertujuan agar anggota kelompok mampu mengidentifikasi respond an perilaku yang muncul dari kejadian yang tidak menyenangkan. Pemeriksa juga memberikan psikoedukasi mengenai kecemasan sebelum tahap pertama intervensi diberikan kepada anggota kelompok. Penerimaan satu dengan lainnya dalam anggota kelompok dinilai cukup baik, AN dan SH menjadi penggerak dan pencair suasana dalam kelompok. Sementara MD cenderung menimpali pendapat yang telah dikemukan oleh AN dan SH. I dan $\mathrm{AD}$ terlihat pasif sehingga terapis perlu untuk memotivasi mereka agar berani untuk menyampaikan pendapat.

Tahap kedua yaitu present moment dan value. Pada tahap ini, terapis mengarahkan anggota untuk dapat mengidentifikasi kejadian yang tidak menyenangkan saat ini dan berusaha untuk mengidentifikasi nilai yang mereka miliki dalam perilaku yang merugikan. Terapis juga menggunakan teknik konfrontasi untuk membantu anggota menyadari bahwa keterbatasan mereka saat ini merupakan konsekuensi yang harus mereka terima dan hadapi. Terapis juga memberikan pemahaman mengenai fungsi dan peran kelompok yang dapat berperan sebagai sumber dukungan moril (support group), yaitu masing-masing anggota kelompok didorong untuk berani memberikan motivasi dan evaluasi bagi anggota kelompok lainnya dalam melakukan perubahan positif.

Tahap ketiga yaitu commitmen action. Terapis mengarahkan kelompok untuk masing-masing memilih salah satu perilaku dan berlatih untuk mengatasi perilaku yang kurang baik berdasarkan nilai yang sudah mereka pilih.

Tahap keempat yaitu commitmen. Terapis mengarahkan kelompok untuk masing-masing mendiskusikan usaha yang dapat dilakukan untuk menghindari perilaku lama, mempertahankan dan mengembangkan perilaku baru. Pada tahap ini, masing-masing anggota kelompok juga menjelaskan manfaat terapi dalam mengatasi kecemasan yang mereka alami setelah memiliki komitmen dan perilaku baru. Pada tahap ini, terapis juga mengarahkan kelompok untuk kembali melakukan latihan dalam mempertahankan komitmen dan perubahan perilaku dalam kegiatan sehari-hari selama berada di dalam lapas.

Tahap kelima memasuki tahapan evaluasi dan terminasi. Terapis memastikan bahwa kelompok tidak menemui hambatan dan memfasilitasi diskusi mengenai langkah preventif. Diskusi mengenai langkah preventif diperlukan untuk mempersiapkan kelompok ketika menghadapi tantangan serupa di masa mendatang. Terapis juga memberikan rangkuman kepada AN, MD, SH, I dan AD untuk melakukan proses yang serupa ketika mengalami kecemasan sebagai keluhan utama pada awal pertemuan kelompok ini. Terapis juga berdiskusi untuk menemukan acceptance dan commitment dari kelompok. Terapis memberikan post tes untuk mengukur kecemasan 
masing-masing anggota kelompok, memberikan kesempatan kepada kelompok untuk memberikan feedback kepada terapis dan terminasi pertemuan dilakukan.

Hasil penelitian ini terbukti bahwa acceptance dan commitment therapy telah mencapai sasaran dan tujuannya, yaitu membuat kelompok mengatasi kecemasan dengan menerima kondisi saat ini dan membangun komitmen untuk menemukan, melatih, mempertahankan dan mengembangkan perilaku baru. Hal ini sejalan dengan hasil penelitian Forman dkk (dalam Hayes, 2010) yang menjelaskan bahwa terapi penerimaan dan komitmen dapat digunakan untuk menangani masalah kecemasan. Berdasarkan hasil pretest dan posttest tingkat kecemasan yang telah dilakukan, terjadi perubahan tingkat kecemasan dari masing-masing anggota kelompok.

Tabel 1. Total Nilai Pretest dan Posttest Tingkat Kecemasan

\begin{tabular}{llllll}
$\begin{array}{l}\text { Pretest } \\
\text { Nama }\end{array}$ & Total Nilai & Kategori & $\begin{array}{l}\text { Posttest } \\
\text { Nama }\end{array}$ & Total Nilai & Kategori \\
\hline AN & 22 & Moderate & AN & 15 & Mild \\
\hline MD & 14 & Mild & MD & 4 & Minimal \\
\hline SH & 21 & Moderate & SH & 5 & Mild \\
\hline I & 19 & Moderate & I & 7 & Minimal \\
\hline AD & 21 & Moderate & AD & 8 & Minimal
\end{tabular}

Masing-masing anggota kelompok juga mampu menerima kondisi mereka saat ini berada di dalam lapas dan menerima kenyataan bahwa mereka harus merubah perilaku negatif. Masing-masing anggota kelompok mampu menemukan nilai baru dan membangun komitmen untuk melakukan perubahan perilaku. Masing-masing anggota kelompok juga mampu melatih komitmen dan perubahan perilaku dalam kegiatan sehari-hari sehingga hasil intervensi yang dilakukan memiliki dampak positif yaitu berkurangnya tingkat kecemasan mereka menjelang pembebasan bersyarat. 


\section{Tabel 2. Perilaku Sebekum dan Sesudah Intervensi}

\begin{tabular}{|c|c|c|}
\hline \multirow[t]{2}{*}{ Peserta } & \multicolumn{2}{|c|}{ Perubahan Perilaku } \\
\hline & Sebelum Intervensi & Sesudah Intervensi \\
\hline AN & $\begin{array}{l}\text { - Mudah marah dan sedih } \\
\text { - Jarang bergaul dengan } \\
\text { teman-teman } \\
\end{array}$ & $\begin{array}{ll}\text { - } & \text { Berbicara lembut } \\
\text { - } & \text { Banyak membaca buku } \\
& \text { pengendalian diri } \\
\end{array}$ \\
\hline MD & $\begin{array}{l}\text { - Selalu berpikir negatif } \\
\text { kepada istri dan mertua } \\
\text { - Malas berkomunikasi } \\
\text { dengan istri }\end{array}$ & $\begin{array}{l}\text { - Belajar mengaji, menulis } \\
\text { arab dan sholat } \\
\text { - Mencoba untuk } \\
\text { berkomunikasi dengan istri }\end{array}$ \\
\hline $\mathrm{SH}$ & $\begin{array}{ll}\text { - } & \text { Mudah marah } \\
\text { - } & \text { Kurang percaya diri }\end{array}$ & $\begin{array}{l}\text { - } \text { Mengakui kesalahan } \\
\text { - Rajin berolahraga dan } \\
\text { membaca buku } \\
\text { pengembangan diri } \\
\end{array}$ \\
\hline $\mathrm{I}$ & $\begin{array}{ll}\text { - } & \text { Sering melamun } \\
\text { - } & \text { Malas mengikuti kegiatan }\end{array}$ & $\begin{array}{l}\text { Melatih ketrampilan } \\
\text { berkomunikasi dan berani } \\
\text { menyampaikan perasaannya. } \\
\text { - Mengajak teman untuk } \\
\text { bersama merapikan kamar. }\end{array}$ \\
\hline $\mathrm{AD}$ & $\begin{array}{ll}\text { - } & \text { Seringkali merasa bingung } \\
\text { - } & \text { Seringkali cemas akan } \\
& \text { kesehatan Ibu }\end{array}$ & $\begin{array}{l}\text { - Mengajak teman menjaga } \\
\text { kerapihan } \\
\text { - Sholat lima waktu dan } \\
\text { melatih ketrampilan } \\
\text { berkomunikasi dengan berani } \\
\text { menyapa orang lain. }\end{array}$ \\
\hline
\end{tabular}

\section{KESIMPULAN}

Narapidana yang menjelang pembebasan mengalami kecemasan yang terkait dengan perasaan takut dan bersalah terhadap situasi dan kondisi yang akan dialaminya ketika kembali ke masyarakat. Kecemasan yang mereka alami berdampak pada perilaku keseharian selama menjalani pembinaan di dalam Lapas.

Terapi penerimaan dan komitmen adalah salah satu bentuk terapi yang digunakan untuk mengurangi kecemasan pada narapidana menjelang pembebasan bersyarat. Dari hasil penelitian yang dilakukan menunjukan bahwa terapi penerimaan dan komitmen berperan dalam mengurangi kecemasan dengan memberikan insight pada setiap anggota kelompok untuk menerima keadaan dan membuat komitmen perubahan perilaku baru berdasarkan nilai yang mereka miliki.

\section{Diskusi}

Penelitian ini memiliki fokus pada peran terapi penerimaan dan komitmen dalam mengurangi kecemasan. Pada penelitian ini, narapidana yang mengikuti terapi menunjukan pengurangan tingkat kecemasan. Melalui terapi penerimaan dan komitmen, narapidana dapat memiliki insight untuk menerima kondisi saat ini dan merubah perilaku mereka dalam keseharian.

Bentuk kegiatan terapi penerimaan dan komitmen yang dilakukan terdiri dari 5 sesi pertemuan dengan durasi 1,5 jam setiap sesinya. Setiap tahap dilakukan dengan diskusi dan terjalin hubungan terapeutik yang hangat antara peneliti dan subyek. Hal ini menjadi penting karena dengan adanya 
hubungan positif, subyek dapat merasa nyaman, aman dan terbuka dengan proses terapi yang dilakukan. Hubungan terapeutik yang positif juga menumbuhkan rasa percaya pada masingmasing anggota kelompok sehingga dapat berperan sebagai kelompok dukungan (support group). Masing-masing anggota kelompok dengan nyaman menceritakan permasalahan mereka dan memberikan konfrontasi yang bersifat membangun ke arah perubahan yang positif.

Interpretasi terhadap gambar dan alat tes tidak dijabarkan secara lengkap karena penelitian ini hanya menekankan pada hasil dari terapi penerimaan dan komitmen dalam mengurangi kecemasan pada narapidana menjelang pembebasan.

\section{Saran}

Saran Bagi Pelaksanaan Terapi Kelompok

Pelaksanaan terapi kelompok disarankan untuk dapat dilakukan dalam durasi per pertemuan dan sesi yang lebih panjang. Hal ini ditujukan agar setiap anggota dapat beradaptasi, membaur, dan lebih terbuka. Selain itu, disarankan agar tersedia sebuah ruangan yang kondusif untuk dapat digunakan, sehingga anggota dapat merasa nyaman di sebuah ruangan kelas yang menetap dan pertemuan dapat dilakukan dengan fokus karena tidak terganggu atau teralih karena ada orang lain yang ingin menggunakan ruangan yang sama.

\section{Saran Bagi Anggota Terapi Kelompok}

Secara umum, masing-masing anggota kelompok direkomendasikan untuk merumuskan keinginan dan melakukan perencanaan yang telah dibuat. Rekomendasi ini diberikan untuk menyadarkan para anggota kelompok bahwa tidak selamanya kehidupan berlangsung sesuai harapan dan oleh karenanya diperlukan kemampuan mereka untuk mewaspadai dan mengatasinya dengan cara seperti yang telah dilakukan di kelompok.

\section{Ucapan Terima Kasih (Acknowledgement)}

Penelitian ini dilakukan dengan bantuan, dukungan dan masukan dari berbagai pihak. Oleh karena itu, peneliti mengucapkan terima kasih dengan tulus kepada semua pihak yang memberikan kontribusinya dalam penelitian ini, antara lain : 1) Widya Risnawaty, M.Psi.,Psikolog dan Ibu Angesty Putri,M.Psi.,Psikolog atas waktu bimbingan dan diskusinya; 2) Bapak Susanto Joseph (alm) dan Ibu Magdalena Joseph selaku orang tua yang tiada hentinya memberikan dukungan materi dan doa; 3) Seluruh responden penelitian, narapidana Lapas X atas kesediaannya untuk berpartisipasi dalam penelitian ini.

\section{REFERENSI}

Aini, Rahmi. 2015. Pengaruh Cognitive Behavior Therapy Terhadap Penurunan Derajat Kecemasan Pada Narapidana Yang Akan Bebas di Lembaga Pemasyarakatan Wanita Kelas IIA Bandung. SCIENTICA. Volume II No. 1

Atkinson, R., Richard, A., Hilgard, E. 1996. Introduction to psychology. New York: Harcourt Brace College Publishers.

Atwater, E. 1983. Psychology of Adjustment : Personal Growth In A Changing World. $2^{\text {nd }}$.Ed. New Jersey : Prentice-Hall.

Bartol, Curt. L. 1994. Psychology and Law. California: Wadsworth Inc.

Beck, Aaron T. 1993. Cognitive Therapy of Substance Abuse. New York: The Guilford Press.

Fahruliana, Rani. 2011. Pengaruh Pemberian Terapi Humor Terhadap Penurunan Tingkat Kecemasan Pada Narapidana Menjelang Masa Pembebasan Di Lembaga Pemasyarakatan Wanita Klas IIA. Malang : UIN

Haber, A., Runyon, R.P. 1984. Psychology of Adjustment. Illinois : The Dorsey Press. 
Hayes, Steven.,Watz, Thomas. 2010. Acceptance and Commitment Therapy In Cognitive Behavioral Therapy in Clinical Practice. New York : The Guilford Press.

Kumar, Ranjit. 1999. Research Methodology. London: SAGE Publications.

Mulyadi, Lilik. 2005. Pengadilan Anak di Indonesia (Teori, Praktik dan Permasalahannya. Bandung: Mandar Maju.

Stroshal, Kirk. 2002. Acceptance and Commitment Therapy. Elseiver USA.

Stuart dan Sundeen. (1998). Buku Saku Keperawatan Jiwa. Jakarta: EGC.

Taylor JA. 1953. A personality Scale of Manifest Anxiety. J Abnorm SocPsychol

Utari, Dewi Indriyani., Fitria, Nita., Rafiyah, Imas. 2013. Gambaran Tingkat Kecemasan pada Warga Binaan Wanita Menjelasan Bebas di Lembaga Pemasyarakatan Wanita Kelas IIA Bandung. Jurnal Imu Keperawatan. Vol I

http://nasional.kompas.com/read/2016/04/10/06500041/Kejahatan.Penjara.dan.Kita?page=all di unduh pada tangga 06 Desember 2017, pkl 16.25 